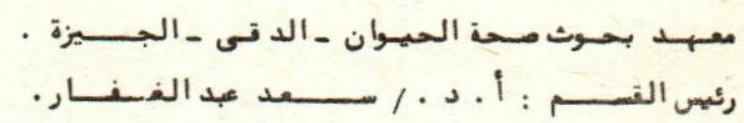

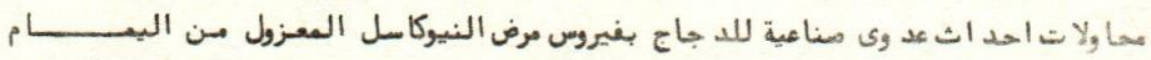

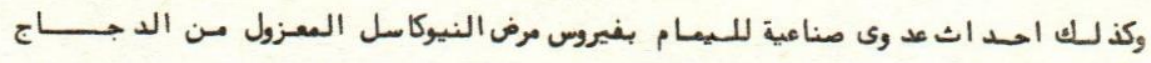

متعبد الصبان ، شـــــــوقى ند يـم ، نرجس برهومه ، أحعد بسيونى ، أحسد سامى ، أحسد أبوزيد

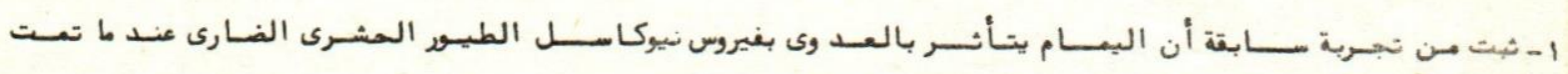

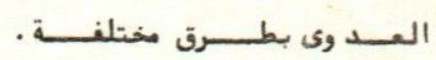

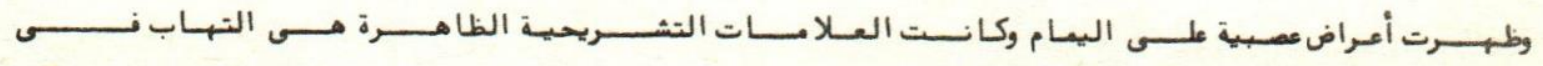

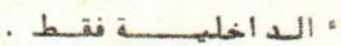

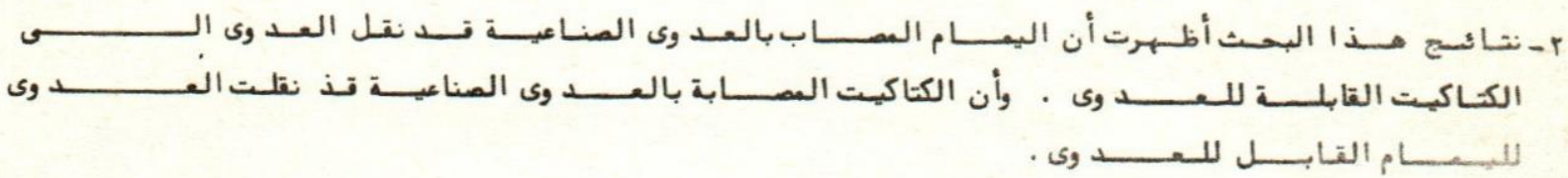

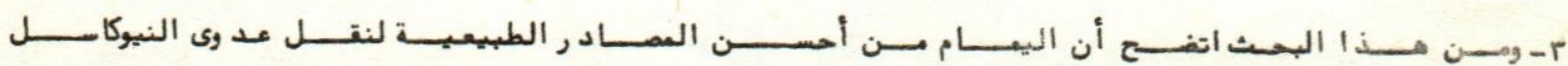

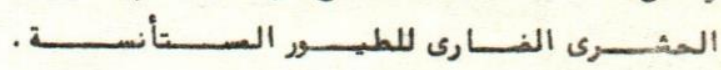


Animal Health Research Institute, Dokki, Egypt.

Head of Dept. Prof. Dr. S. Abd El-Ghaffar.

\section{TRIAL OF TRANSMISSION OF VELOGENIC VISCEROTROPIC NEWCASTIE VIRUS FROM INFECTED DOVES "STREPTOPLIA SENEGALENSIS AEGYPTIACUS" TO SUSCEPTIBLE CHICKENS AND FROM INFECTIED CHICKENS TO SUSCPTIBLE DOVES \\ (With One Table)}

By

A. ABOU ZIED, A.A. SAMI, A.A. BASIONI, N.M. BARHOUMA, S.N. IBRAHIM, M.S. SABBAN, (Received at $17 / 11 / 1981$ )

\section{SUMMARY}

1. In a previous experiment it was proved that doves responded to the VVNDV given by different routes with nervous symptoms and congestion of the internal organs.

2. This experiment showed that infected doves transmitted the VuNDV to susceptible chickens and that infected chickens transmitted the disease to susceptible doves.

3. So doves acted as good transmittors of VVNDV to domesticated chickens.

\section{INTRODUCTION}

In a previous experiment, experimental infection of the Egyptian doves with the VVNDV using different rotues showed that these birds responded to the virus and showed nervous symtras and died with congestion of the internal organs

There are different opinions about the susceptibility of doves and their role in the transmission of Newcastle disease virus to domesticated chicks. MAGID et al. (1963) reported that the Nile sparrow "Passer domesticus riboticus) and the Egyptian dove (Streptopelia senegalensis aegyptiacus) resisted infection when N.D.V. was administered orally. The feces were free from the virus and that doves and sparrows placed in contact with ND infected chickens failed to conract the disease. Although ND of pigeons and doves had been reported by several workers (PICARD, 1928; VRTIAK, 1958; MARSTONI and SIDOLI, 1959; ULBRICH and SODAN,1956). On the other hand other observers had noted a lack of apparent infection of pigeons and doves subjected to propable natural exposure (CRAWFORD,1931; BIARCHI, 1941; ORR and JOHN, 1946; ADLRR et al.., 1951). More workers reported that pigeons and doves are usually resistant to overt disease by experimental, oral or contact exposure (KEB, 1928, ADLER et al..1951;and SANTuCCI, 1956; BACZYNSKI, 1960 a).

In the following experiment a trial was made to find out the role played by the Egyptian doves in the transmission of the VYNDV to chickens.

\section{MATERIALS AND METHODS}

Birds:

10 doves were purchased $\mathrm{from}$ the local market that were in good condition. One day old chicks were taken :from the poultry company, were coming from vaccinated parents and were kept in an isolated place for 6 weeks to get rid of the prenatal immunity.

\section{The Virus:}

The virus used in the experiment is the velogenic viscerotropic Newcastle disease virus locally isolated and characterized and proved to be the vVNDV. It was lyophized and titrated in chick embryos and gave a titer of $10^{-8.25 \text {. }}$

- "This research is a part of a.thesis prepared by the senior author It has been financed in part by a grant made by the United States Department of Agriculture, Agriculture Research Service, authorized by Public Law 480." 


\section{Experimental:}

All birds were kept under observation for 3 days and blood samples and feacal swabs were taken from all birds before inoculation and all gave 1:0 HI titer and negative for the trail of isolation of the virus proving that all the birds used in the experiment were fully susceptible.

\section{Experimental:}

The birds were devided into two groups, each constituted 5 doves and 5 chicks. Each group was kept in a separate cage. They were given the VVNDV as follows:

Group 1:

The five doves were each given one million infective doses of the virus per os, and the chickens were left uninoculated as susceptible contacts.

\section{Group 2:}

The five chickens were each given one million infective doses of the virus per os and the doves were left uninoculated as susceptible contacts.

Feacal swabs were taken from all the bids every day during the experiment. Blood samples were collected from all birds every 10 days.

RESULTS

As shown in Table 1 , in the first group all the 5 inoculated do es showed nervous symptoms and died between the 6 th to the 28 th day of inoculation and the lesions were congestion of the internal organs. All the 5 inoculated doves shed the virus from the intestine on the first till the 4 th day, the HI titer of blood reached 1:40 on the 20 th day of inoculation and the virus was recovered from the internal organs of all the dead doves. In the same group the contact susceptible chickens contracted the disease from the inoculated doves, as they showed typical symptoms and lesions and shed the virus from the 2 nd to the 3 rd day and virus was recovered from the internal organs of all dead chickens. All the inoculated chickens of the second group showed typical symptoms and lesions, shed the virus and virus was recovered from the internal organs of all dead chicks. The susceptible contact doves contracted the disease from the inoculated chicks, showed nervous symptoms,..congestion.of internal organs and died from the 11 th to the 24 th day of being in contact. The virus was recovered from the internal organs of all dead doves and $\mathrm{HI}$ titer reached 1:40 to the 20th day of contanct.

\section{DISCUSSION}

The results of the previous experiment on the susceptiblility of the Egyptian doves"Senegalensis aegyptiaacus showed that these birds responded to the velogenic viscerotropic Newcastle disease virus when given by different routes. They showed nervous symptoms and congestion of the internal organs. In this experiment when susceptible chickens were kept in contact with inoculated doves they contracted the disease and when susceptible doves were kept in contact with inoculated chicks they contracted the disease. So doves here acted as good transmittors of the VVNDV. These results were different from those obtained by MAGID (1965) who reported that Egyptian doves resisted infection when N.D.V. was administered orally and that doves placed in contanct with ND infected ehickens failed to contract the disease. Probably the difference in results might be attributed to the type of virus used and the dose given. Although some workers supported the infection of doves with Newcastle disease (VRTIAK, 1958; MARASTONI, 1950; ULBRICH, 1965; CRAWFORD, 1931) other workers had noted a lack of apparent infection of pigenos and doves subjected to probable natural exposure (BIANCHI, 1941; ORR, 1946; ADLER, 1951 and KEE, 1928).

\section{REFERENCES}

Aaler, H.E., Willers, E.H. and Campbell. J. (1951): Newcastle disease (avian) pneumoeneephalitis in Hawail. Am. J. Vet. Res. $12,44$.

Bianchi,E. Sulla (1941): Nature of the poultry disease at present occurring in Italy. Clin. Vet. 64 : 325.

Crawford,M. (1931): Ranikhet disease. Rept. Gov. Vet. Surg. for 1930. Colombo Ceylon P. 47. 
Kee,F.G. (1928): Notes on an outbreak of poultry epidemic. Fhillipine Agriculturist. $17.263,47: 1140$.

Magid,I.M.A.; Mohamed A.A.A. and Nasri,B.B. (1965): Newcastle disease and sparrows. J. Arab. Vet. Med. Assoc. 25

(4); $193,202$.

Marastoni,G. and Sidoli,L. (1959): An outbreak of Newcastle disease in pigeons. Vet. Ital. 10: 349.

Orr, W., and John, Kit. (1946): Malayan virus of fowls. Vet. Rec. 58 : 117.

Picard, W.R. (1928): Paseudofowlpest vecartsenijkun-dige Mededeeling 65, 1.

ulbrich,F. and Sodan,U. (1965): Natural infection in pigeons with Newcastle disease virus, Mh. Vet. Med, 20 : 3:340.

Vrtiak, J. (1958): Epizootologicke zviastnosi castiskej choroby na vychodnom siovensku. Sb. Cask. Akad. Zemedel. vet. $31(3): 437$

\section{TABLE (1)}

Trial of Transmission of VVNDV from Doves to Chickens and from Cnickens to Doves.

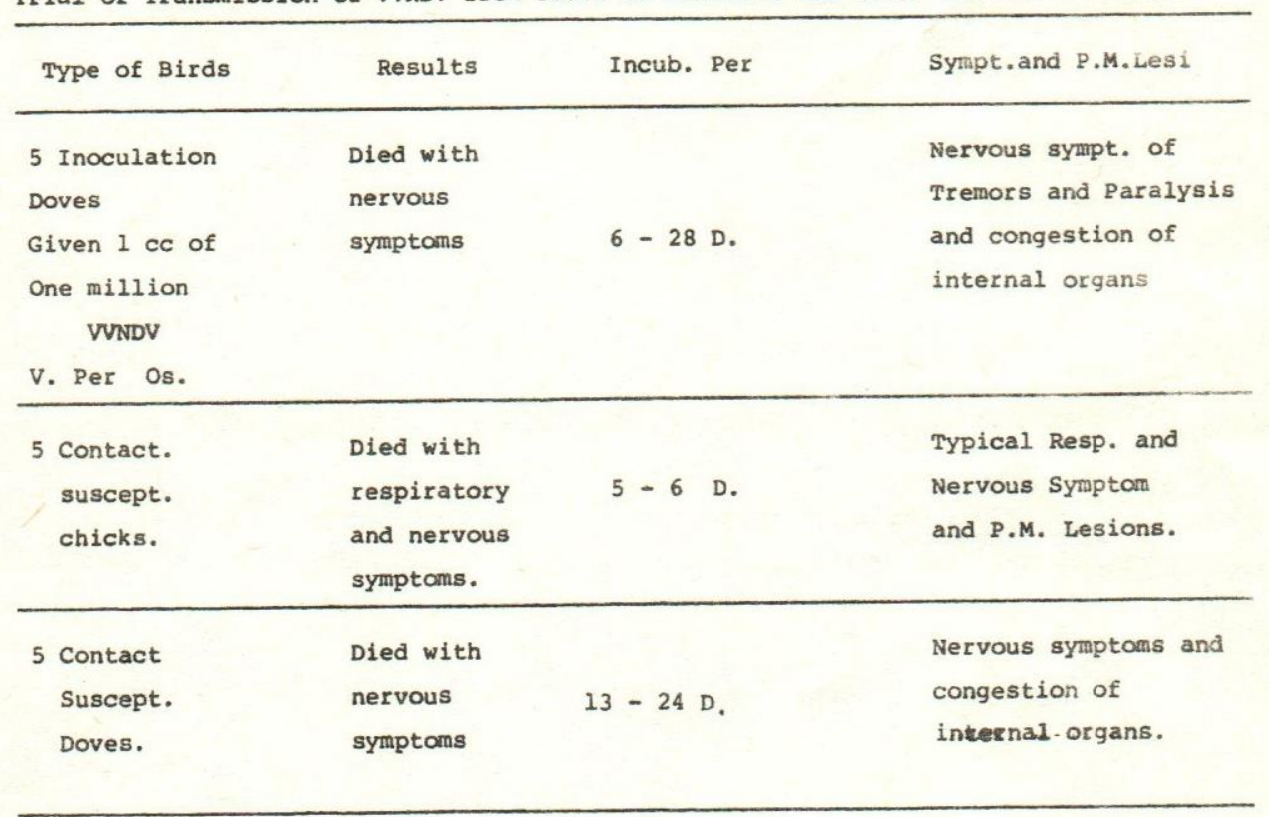

\begin{tabular}{|c|c|c|}
\hline Shedding of Virus & HI Test & $\begin{array}{l}\text { Virus } \\
\text { Isolation }\end{array}$ \\
\hline $\begin{array}{l}\text { Shed virus from first or second day of } \\
\text { inoculation till the } 4 \text { th day. }\end{array}$ & $\begin{array}{l}\text { Preinoc. } 1: 0 \\
\text { or d aftiai } 1: 0 \\
20 d^{n} \text { " } 1: 40\end{array}$ & + \\
\hline Shed virus from the 2 nd to the 5 th day. & $\begin{array}{l}\text { Preinoc. 1:0 } \\
\text { Died before blood } \\
\text { collected. }\end{array}$ & + \\
\hline Shed virus from the 2 nd to the 6 th day. & $\begin{array}{l}\text { Preinoc. 1:0 } \\
\text { Died before } \\
\text { blood collected. }\end{array}$ & + \\
\hline $\begin{array}{l}\text { Shed virus in } 2 \text { out of } 5 \text { doves on the } \\
12 \text { day in the first and } 21,22 \& 25 \text { d } \\
\text { in the second. }\end{array}$ & $\begin{array}{ll}\text { Preinoc. } & 1: 0 \\
2 \text { od. } & 1: 40\end{array}$ & + \\
\hline
\end{tabular}


